\title{
Stress of nursing professionals working in pre-hospital care
}

\author{
Estresse dos profissionais de enfermagem atuantes no atendimento pré-hospitalar \\ Estrés de los profesionales de enfermería actuantes en la atención prehospitalaria
}

Ana Elizabeth Lopes de Carvalho' ORCID: 0000-0002-5250-330X

Iracema da Silva Frazão" ORCID: 0000-0002-4690-3753

Darine Marie Rodrigues da Silva' ORCID: 0000-0001-9111-6380

Maria Sandra Andrade' ORCID: 0000-0002-9551-528X

Selene Cordeiro Vasconcelos"'I ORCID: 0000-0002-8828-1251

Jael Maria de Aquino' ORCID: 0000-0001-5095-1662

'Universidade de Pernambuco. Recife, Pernambuco, Brazil. "Universidade Federal de Pernambuco. Recife, Pernambuco, Brazil. "' Universidade Federal da Paraíba. João Pessoa, Paraíba, Brazil.

How to cite this article: Carvalho AEL, Frazão IS, Silva DMR, Andrade MS, Vasconcelos SC, Aquino JM. Stress of nursing professionals working in pre-hospital care. Rev Bras Enferm. 2020;73(2):e20180660. doi: http://dx.doi.org/10.1590/0034-7167-2018-0660

Corresponding Author: Ana Elizabeth Lopes de Carvalho E-mail: bethlopes32@gmail.com

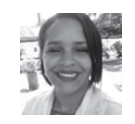

EDITOR IN CHIEF: Antonio José de Almeida Filho ASSOCIATE EDITOR: Italo Rodolfo Silva

Submission: 05-01-2019

Approval: 05-01-2019

\begin{abstract}
Objectives: To analyze the factors related to the occupational stress of a Mobile Emergency Care Service (Samu) nursing team. Methods: This is a descriptive study, with a quantitative approach, performed with nursing professionals from Samu service of a city of Pernambuco. A sociodemographic questionnaire and the Lipp's Stress Symptom Inventory were used. Results: The participants presenting stress (24.6\%) were classified in the phases: resistance (19.7\%), exhaustion (4.4\%) and near exhaustion (0.5\%). It was also observed an association of stress level with the following factors: gender, sleep quality, professional autonomy restriction, emotional exhaustion with work performed and work in inadequate or unhealthy physical facilities. Conclusions: Although showing low occurrence of stress, this study pointed out the profile that presents the highest risk of developing occupational stress, through the factors significantly associated with stress in the studied population.
\end{abstract}

Descriptors: Burnout, Professional; Nurse Practitioners: Emergency Medical Services; Emergencies; Occupational Stress.

\section{RESUMO}

Objetivos: Analisar os fatores relacionados ao estresse ocupacional da equipe de enfermagem de um Serviço de Atendimento Móvel de Urgência (Samu). Métodos: Estudo descritivo, com abordagem quantitativa, realizado com profissionais de enfermagem do Samu de um município de Pernambuco. Foram utilizados um questionário sociodemográfico e o Inventário de Sintomas de Stress de Lipp. Resultados: Os participantes que apresentaram estresse $(24,6 \%)$ foram classificados nas fases: de resistência (19,7\%), de exaustão $(4,4 \%)$ e de quase exaustão $(0,5 \%)$. Observou-se, ainda, associação do nível de estresse relacionado com os seguintes fatores: sexo, qualidade de sono, restrição da autonomia profissional, desgaste emocional com o trabalho que realiza e trabalho em instalações físicas inadequadas ou insalubres. Conclusões: Apesar de evidenciar baixa ocorrência de estresse, este estudo apontou qual o perfil que apresenta maior chance de risco de desenvolver estresse ocupacional, por meio dos fatores que estiveram associados, significativamente, com o estresse na população estudada.

Descritores: Esgotamento Profissional; Profissionais de Enfermagem; Serviços Médicos de Emergência; Emergências; Estresse Ocupacional.

\section{RESUMEN}

Objetivos: Evaluar los factores asociados al estrés laboral del personal de enfermería de un Servicio de Atención Móvil de Urgencia (Samu). Métodos: Estudio descriptivo, con abordaje cuantitativo, en el cual participaron profesionales de enfermería del Samu de un municipio de Pernambuco (Brasil). Se utilizaron un cuestionario sociodemográfico y el Inventario de Síntomas de Estrés de Lipp. Resultados: Los participantes que presentaron estrés $(24,6 \%)$ fueron clasificados en las fases: de resistencia $(19,7 \%)$, de agotamiento $(4,4 \%)$ y de cuasiagotamiento $(0,5 \%)$. Además, se observó una asociación entre el nivel de estrés y los siguientes factores: sexo, calidad de sueño, restricción de la autonomía profesional, desgaste emocional con el trabajo que realiza y trabajo en instalaciones físicas inadecuadas o insalubres. Conclusiones: A pesar de apuntar una baja ocurrencia de estrés, el presente estudio muestra el perfil que presenta una mayor probabilidad de riesgo de desarrollar estrés laboral, mediante los factores que estuvieron asociados significativamente con el estrés en la población estudiada.

Descriptores: Agotamiento Profesional; Enfermeras Practicantes; Servicios Médicos de Urgencia; Urgencias Médicas; Estrés Laboral. 


\section{INTRODUCTION}

Work has great importance in the life of individuals. It can offer income, self-esteem, a chance for personal growth and social identity. However, labor can negatively affect health, appearing as a source of stress and exposing the worker to occupational stress ${ }^{(1)}$. This condition offers physical or mental symptoms as a result of workplace events and/or activities. Besides being able to be related to the environment and work overloads, this type of stress can be associated with the situations that destructured the worker(2).

In this context, nursing professionals who, in their working day, can be submitted to a level of stress that causes physical and psychic damages ${ }^{(3)}$ stand out. Among the different nursing areas, the emergency, where the Pre-Hospital Care (APH) service fits, is considered to be the one with the greatest stress, mainly due to the work process, which requires physical, mental, psychological and emotional efforts. Routine and work stress may result in occupational stress and interfere with personal and professional behavior, outcomes, efficacy and quality of life ${ }^{(4)}$. The wear presented by the worker can increase the stress and directly interfere in their quality of life and health ${ }^{(3)}$.

Occupational stress is a result of the way a person deals with the needs of the job and how they cope with it. There are several sources of stress that can interfere with the level of individual stress presented by the individual ${ }^{(2)}$. In this sense, to deal with stressful situations, several coping strategies can be used, allowing one to live those situations better, avoiding a pathological condition ${ }^{(5)}$. It is important that nursing professionals recognize, therefore, the stressing agents of the work environment ${ }^{(6)}$.

When considering the work routine of PHC nursing professionals and their risk to stress, it is relevant to identify the occupational stress and stressors that are part of the daily routine. In this sense, it is expected to favor the development of actions of stress prevention and, mainly, the health promotion of these workers.

\section{OBJECTIVES}

To analyze the factors related to occupational stress of the nursing team of a Mobile Emergency Care Service (Samu).

\section{METHODS}

\section{Ethical aspects}

This study was approved by the Research Ethics Committee involving human beings of the Hospital Complex HUOC/Procape, University of Pernambuco and approved in compliance with Resolution 466/2012, the National Health Council/MS, which regulates research and testing involving humans.

\section{Study design, location and period}

This is descriptive study, with a quantitative approach, carried out with nursing professionals from Samu, in a municipality of Pernambuco. This is a part of the dissertation entitled Stress of the Nursing Professionals Who Work in the Mobile Emergency Care Service (Samu), presented to the Associate Nursing Graduation
Program of the University of Pernambuco and State University of Paraíba.

\section{Population and sample}

The studied population consisted of 59 nurses, 151 nursing technicians and 8 nursing assistants, part of the nursing professionals staff from Samu of a city of Pernambuco, from a total of 218 professionals. The sample obtained a total of 56 nurses, 139 nursing technicians and 8 auxiliaries, totaling 203 participants.

The criterion of inclusion was: to be a nursing professional, working in the nursing care within the vehicles or medical regulation with at least one year of service time. Workers on premium leave, maternity leave or medical leave were excluded from the study during the data collection period.

\section{Study protocol}

The data collection was performed through interviews, and the Lipp's Stress Symptoms Inventory (LSSI) and sociodemographic questionnaire were applied. The LSSI was standardized by Lipp and Guevara ${ }^{(7)}$, based on the three-phase stress model proposed by Selye. During this standardization, a fourth phase, called near exhaustion, was recognized, which is inserted between the resistance and exhaustion phases ${ }^{(7)}$. The LSSI allows to verify the stress in adults, the stage of stress to which the person is subjected (alert, resistance, near exhaustion and exhaustion) and the predominance of physical and/or psychological symptoms at each stage ${ }^{(8)}$.

The positive diagnosis of stress is obtained by the sum of the symptoms seen in each frame of the instrument. In this sense, when the threshold value is exceeded in a given phase, the presence of the stress and its phase is verified, which is seen as: alert phase $(\mathrm{Q} 1>6$ symptoms); resistance phase $(\mathrm{Q} 2>3)$; near exhaustion phase $(\mathrm{Q} 2>9)$; and exhaustion $(\mathrm{Q} 3>8 \text { symptoms })^{(9)}$.

Day and night shift workers at the Central Base and the Decentralized Bases of Samu signed the Informed Consent Form (TCLE) and completed the research instruments in a reserved place, using about 15 minutes for their answers.

\section{Analysis of results and statistics}

The data were described in absolute and percentage distribution, uni and bivariate, for the categorical variables. They were inferentially analyzed by the Pearson chi-square test. OddsRatio (OR) or Chances Ratio (CR) were obtained to evaluate the strength of the association, and confidence intervals for this measure were obtained in the study of the association between the variables in the bivariate study.

The margin of error used in the statistical test decisions was $5 \%$ and the intervals were obtained with $95 \%$ confidence. The Statistical Package for the Social Sciences (SPSS), in version 23, was used to enter the data and to obtain the statistical calculations.

\section{RESULTS}

The sample consisted of 203 participants. Fifteen professionals who did not meet the inclusion criteria were excluded, ten were 
exclusively administrative or had less than one year of service, and five were separated by medical leave. Of these, three (two nurses and one nursing technician) with medical leave for depression. Of the sample studied, $94.6 \%$ worked in the assistance of the Advanced Support Unit, Basic Support Unit and by Motorcycle, $3.4 \%$ worked in medical assistance and regulation and $2.0 \%$ worked only in regulation.

The socio-demographic data showed three most frequent age groups: $40-44$ years old (26.1\%), 35-39 years old $(23.2 \%)$ and 45-49 years old (20.7\%), with female (76.8\%) and brown colored people (46.8\%) predominance. The predominant professional category was nursing technicians $(68.5 \%)$, followed by nurses (27.6\%) and nursing assistants (3.9\%).

Regarding the evaluation of the stress classification, it was observed that approximately $75.4 \%$ of the participants were classified without stress. Those who presented stress (24.6\%) were classified in the resistance phase (19.7\%), exhaustion (4.4\%), near exhaustion $(0.5 \%)$ and none in the alert phase. There was no association between stress levels and professional categories.

Table 1 shows that, when assessing the occurrence of stress according to age, gender, physical activity and time of service, it was verified that gender was the only variable that presented a significant association with stress ( $p<0.05$, OR 2.69 and range excluding 1.00$)$, being higher among female professionals (28.2\%) than in male (12.8\%).

Of the variables contained in Table 2, sleep quality was the only variable that showed a significant association with stress, and it was observed that most of the participants with stress had their sleep quality affected, evidenced by the values found for great (3.7\%), good (16.0\%), regular (32.9\%) and bad/terrible $(24.6 \%)$ sleep quality.

Table 3 shows a significant association of stress with each of the questions: working in inadequate physical facilities, yes (34.3\%) and no (15.4\%); working in an unhealthy environment ( $27.8 \%$ and $13.3 \%$, respectively); feeling a restriction on professional autonomy (38.2\% and $17.8 \%$, respectively); emotional weariness with the work done ( $31.2 \%$ and $13.3 \%$, respectively).

Table 4 shows that approximately $3 / 4$ (75.4\%) was classified without stress. Among those classified as stress, resistance was the most frequent phase with $19.7 \%$, followed by exhaustion with $4.4 \%$. Only one professional was near exhaustion and none were on alert.

Table 1 - Evaluation of the occurrence of stress according to age, gender and time of service in Samu, Recife, Pernambuco, Brazil, 2016

\begin{tabular}{|c|c|c|c|c|c|c|c|c|}
\hline \multirow{3}{*}{ Variable } & \multicolumn{4}{|c|}{ Stress } & \multirow{2}{*}{\multicolumn{2}{|c|}{ Total }} & \multirow{3}{*}{$p$ value } & \multirow{3}{*}{ OR (95\% Cl) } \\
\hline & \multirow{3}{*}{ n } & \multirow{3}{*}{$\%$} & \multirow{2}{*}{\multicolumn{2}{|c|}{ n $^{\text {Without }}$}} & & & & \\
\hline & & & & & \multirow[t]{2}{*}{$\mathbf{n}$} & \multirow{2}{*}{ al $\%$} & & \\
\hline Age group & & & & & & & $p^{1}=0.159$ & \\
\hline 25 to 34 & 10 & 27.0 & 27 & 73.0 & 37 & 100.0 & & 4.07 (0.81 a 20.57) \\
\hline 35 to 39 & 16 & 34.0 & 31 & 66.0 & 47 & 100.0 & & 5.67 (1.18 a 27.24) \\
\hline 40 to 44 & 14 & 26.6 & 39 & 73.6 & 53 & 100.0 & & $3.95(0.82$ a 19.00$)$ \\
\hline 45 to 49 & 8 & 19.0 & 34 & 81.0 & 42 & 100.0 & & $2.59(0.50$ a 13.34$)$ \\
\hline More than 50 & 2 & 8.3 & 22 & 91.7 & 24 & 100.0 & & 1.00 \\
\hline Gender & & & & & & & $\mathrm{p}^{1}=0.031^{*}$ & \\
\hline Male & 6 & 12.8 & 41 & 87.2 & 47 & 100.0 & & 1.00 \\
\hline Female & 44 & 28.2 & 112 & 71.8 & 156 & 100.0 & & 2.69 (1.07 a 6.77) \\
\hline Service time in Samu & & & & & & & $p^{1}=0.152$ & \\
\hline 1 to 5 years & 20 & 19.0 & 85 & 81.0 & 105 & 100.0 & & 1.00 \\
\hline 6 to 10 years & 19 & 35.2 & 35 & 64.8 & 54 & 100.0 & & 2.31 (1.10 a 4.84) \\
\hline 11 to 15 years & 7 & 28.0 & 18 & 72.0 & 25 & 100.0 & & 1.65 (0.61 a 4.49) \\
\hline More than 15 years & 4 & 21.1 & 15 & 78.9 & 19 & 100.0 & & 1.13 (0.34 a 3.78$)$ \\
\hline Total Group & 50 & 24.6 & 153 & 75.4 & 203 & 100.0 & & \\
\hline
\end{tabular}

Note: (*): significant association at 5\%; (1): by Pearson's Chi-square test.

Table 2 - Evaluation of the occurrence of stress according to the data related to the rest period, number of occurrences per shift and sleep quality, Recife, Pernambuco, Brazil, 2016

\begin{tabular}{|c|c|c|c|c|c|c|c|c|}
\hline \multirow{3}{*}{ Variable } & \multicolumn{4}{|c|}{ Stress } & \multirow{2}{*}{\multicolumn{2}{|c|}{ Total }} & \multirow{3}{*}{$p$ value } & \multirow{3}{*}{ OR $(95 \% \mathrm{Cl})$} \\
\hline & \multicolumn{2}{|c|}{ With } & \multicolumn{2}{|c|}{ Without } & & & & \\
\hline & $\mathbf{n}$ & $\%$ & $\mathbf{n}$ & $\%$ & $\mathbf{n}$ & $\%$ & & \\
\hline Rest during work hours? & & & & & & & $p^{1}=0.131$ & \\
\hline Yes & 25 & 30.1 & 58 & 69.9 & 83 & 100.0 & & $1.64(0.86$ a 3.12$)$ \\
\hline No & 25 & 20.8 & 95 & 79.2 & 120 & 100.0 & & 1.00 \\
\hline On average, how many occurrences are done per shift? & & & & & & & $p^{1}=0.161$ & \\
\hline Up to 3 & 23 & 31.1 & 51 & 68.9 & 74 & 100.0 & & 1.22 (0.51 a 2.93) \\
\hline 4 to 5 & 17 & 18.5 & 75 & 81.5 & 92 & 100.0 & & $0.61(0.25$ a 1.50$)$ \\
\hline 6 or more & 10 & 27.0 & 27 & 73.0 & 37 & 100.0 & & 1.00 \\
\hline What is the quality of your sleep? & & & & & & & $\mathrm{p}^{1}<0.001^{*}$ & \\
\hline Excellent & 1 & 3.7 & 26 & 96.3 & 27 & 100.0 & & ** \\
\hline Good & 13 & 16.0 & 68 & 84.0 & 81 & 100.0 & & ** \\
\hline Regular & 26 & 32.9 & 53 & 67.1 & 79 & 100.0 & & ** \\
\hline Bad/Terrible & 10 & 62.5 & 6 & 37.5 & 16 & 100.0 & & ** \\
\hline Total Group & 50 & 24.6 & 153 & 75.4 & 203 & 100.0 & & \\
\hline
\end{tabular}

Note: $\left.{ }^{*}\right)$ : significant association at $5 \% ;\left(^{* *}\right)$ : not determined due to the occurrence of very low frequencies; (1): by Pearson's Chi-square test. 
Table 3 - Evaluation of stress according to work-related factors, Recife, Pernambuco, Brazil, 2016

\begin{tabular}{|c|c|c|c|c|c|c|c|c|}
\hline \multirow{3}{*}{ Variable } & \multicolumn{4}{|c|}{ Stress } & & & \multirow{3}{*}{$p$ value } & \multirow{3}{*}{ OR $(95 \% \mathrm{Cl})$} \\
\hline & \multicolumn{2}{|c|}{ With } & \multicolumn{2}{|c|}{ Without } & \multicolumn{2}{|c|}{ Total } & & \\
\hline & $\mathbf{n}$ & $\%$ & $\mathbf{n}$ & $\%$ & $\mathbf{n}$ & $\%$ & & \\
\hline Do you work in inadequate physical facilities? & & & & & & & $p^{1}=0.002^{*}$ & \\
\hline Yes & 34 & 34.3 & 65 & 65.7 & 99 & 100.0 & & $2.88(1.47$ a 5.65$)$ \\
\hline No & 16 & 15.4 & 88 & 84.6 & 104 & 100.0 & & 1.00 \\
\hline Do you work in an unhealthy environment? & & & & & & & $\mathrm{p}^{1}=0.046^{*}$ & \\
\hline Yes & 44 & 27.8 & 114 & 72.2 & 158 & 100.0 & & $2.51(0.99$ a 6.34$)$ \\
\hline No & 6 & 13.3 & 39 & 86.7 & 45 & 100.0 & & 1.00 \\
\hline Do you feel that you have a restriction on professional autonomy? & & & & & & & $\mathrm{p}^{1}=0.001^{*}$ & \\
\hline Yes & 26 & 38.2 & 42 & 61.8 & 68 & 100.0 & & $2.86(1.48$ a 5.53$)$ \\
\hline No & 24 & 17.8 & 111 & 82.2 & 135 & 100.0 & & 1.00 \\
\hline Do you feel emotional wear with the work you do? & & & & & & & $p^{1}=0.004^{*}$ & \\
\hline Yes & 40 & 31.2 & 88 & 68.8 & 128 & 100.0 & & $2.96(1.38$ a 6.34$)$ \\
\hline No & 10 & 13.3 & 65 & 86.7 & 75 & 100.0 & & 1.00 \\
\hline Total Group & 50 & 24.6 & 153 & 75.4 & 203 & 100.0 & & \\
\hline
\end{tabular}

Note: (*): significant association at 5\%; (1): by Pearson's Chi-square test.

Table 4 - Evaluation of the stress classification, Recife, Pernambuco, Brazil, 2016

\begin{tabular}{lc}
\hline Variable & $\mathbf{n}(\%)$ \\
\hline Stress rating & \\
$\quad$ No stress & $153(75.4)$ \\
Alert & - \\
Resistance & $40(19.7)$ \\
Near exhaustion & $1(0.5)$ \\
Exhaustion & $9(4.4)$ \\
Total & $203(100.0)$
\end{tabular}

Table 5 - Dominant symptoms according to the classification of stress, Recife, Pernambuco, Brazil, 2016

\begin{tabular}{lccccccccc}
\hline & \multicolumn{9}{c}{ Dominant symptoms } \\
Stress rating & \multicolumn{2}{c}{ Physic } & \multicolumn{2}{c}{ Psychological } & \multicolumn{2}{c}{ Tie } & \multicolumn{2}{c}{ Total } \\
& $\mathbf{n}$ & $\mathbf{\%}$ & $\mathbf{n}$ & $\mathbf{\%}$ & $\mathbf{n}$ & $\%$ & $\mathbf{n}$ & $\%$ \\
\hline Resistance & 37 & 92.5 & 2 & 2.5 & 1 & 5.0 & 40 & 100.0 \\
Near exhaustion & 1 & 100.0 & - & - & - & - & 1 & 100.0 \\
Exhaustion & 5 & 55.6 & 4 & 44.4 & - & - & 9 & 100.0 \\
Total Group & 43 & 86.0 & 5 & 10.0 & 2 & 4.0 & 50 & 100.0 \\
\hline
\end{tabular}

Table 5 shows that, from most of the 50 professionals classified with stress $(86.0 \%)$, a total of $10.0 \%$ had psychological symptoms and in $4.0 \%$ there was a tie in the number of symptoms. It was also verified that most of them had physical symptoms, and the highest frequency with psychological symptoms was registered among the subjects classified with exhaustion (44.4\%).

\section{DISCUSSION}

In this study, the factors related to the occupational stress of the Samu nursing team were related to women, sleep quality, working in inadequate physical facilities, in an unhealthy environment, having a restriction of professional autonomy and a feeling of emotional exhaustion with the work performed. Professionals classified with stress, mostly, reported psychological and physical symptoms.

In a study carried out in Paraná, women were also related to a higher level of stress ${ }^{(10)}$. This reality may be associated to the historical context of nursing, with a predominance of female members ${ }^{(11)}$. A study carried out at national level to chart the nursing profile in Brazil identified that $85.1 \%$ of nurses are women, with higher percentage of technicians and/or nursing assistants $(77 \%)$ in the team ${ }^{(12)}$. This fact can also be justified by the double or triple working day of these professionals ${ }^{(13)}$.

The predominance of physical symptoms among those who were classified with stress and the psychological symptoms observed among participants with exhaustion can be justified by the stress itself, capable of affecting the individual, causing organic and psychic changes, especially the cognitive system ${ }^{(5)}$.

Regarding individuals who presented stress, a larger quantitative in the resistance phase was evidenced, which is seen as the transition phase between positive and negative stress. Therefore, the importance of knowing stressors agents to prevent the progression of stress to levels that compromise workers' health ${ }^{(13)}$ is highlighted. The result of the application of the Lipp's Stress Symptom Inventory for Adults was similar to the study carried out with professionals from a Samu team from Fortaleza, who found that most participants did not present stress. Those who presented were included in the resistance/near exhaustion phase and only one in the exhaustion phase $\mathrm{e}^{(14)}$.

Working conditions are seen as a factor capable of generating stress in health professionals. This reality was present in this study, since the work in inadequate physical facilities was associated with the stress of the participants. The physical space is fundamental to guarantee a good performance in the work of the professionals who act in emergency care ${ }^{(15)}$.

The unhealthy work environment was also pointed as an intrinsic factor and directly related to occupational stress. When working in unhealthy conditions, professionals are more vulnerable to illness ${ }^{(16)}$. People working in $\mathrm{PHC}$, because they are frequently exposed to several occupational hazards, are more prone to suffering from accidents and acquiring pathologies and injuries ${ }^{(17)}$.

The presence of emotional exhaustion related to the work performed by the professional showed a significant association with the occurrence of stress. The emergency work routine itself is a factor capable of affecting the worker's emotional condition, and long-term exposure to occupational stress can trigger the development of emotional exhaustion syndrome, which gives the wearer emotional exhaustion ${ }^{(6,18)}$. 
Lack of professional autonomy can cause worker stress ${ }^{(19)}$. As observed in this study, most of the participants, who did not have stress, did not show professional autonomy restriction. Among those who presented stress, most of them had autonomy restriction.

To consider the factors that generate stress is one of the most important components for the health and safety of a workplace. These factors should be seen as part of a multidimensional system that encompasses work, workers and the environment. It also includes the analysis of how the work process is structured, the organizational culture, values and beliefs that are practiced by the institution ${ }^{(20)}$.

It is important to consider that nurses feel like emergency calls, in general, are stressful. Studies that evaluated stressors related to the work of the nursing team in emergency care evidenced work-related fatigue and musculoskeletal disorders. As well as the presence of higher emotional exhaustion scores associated with depression, anxiety, traumatic experience and perceived stress ${ }^{(21-23)}$.

To minimize the problem, there is a need for a service management and policy-makers' action so that they can make decisions based on information about the stress-generating aspects ${ }^{(21)}$. It is also important to develop educational interventions in the work environment. These actions can help health professionals develop personal skills in dealing with the critical conditions characteristic of their work and enable them to recognize potential risk factors that favor occupational stress ${ }^{(22)}$.

Management focused on aspects identified as stressors can reduce the problem and contribute to workers' quality of life. The lack of control of stressors can have crucial implications in maintaining the patient-professional relationship of health and in reducing clinical errors ${ }^{(22)}$. As a way to minimize stressors, discussions with colleagues, especially when they are organized immediately after a stressful event, characterized as short-term support. It is also important to organize scheduled sessions where stressful cases can be regularly discussed ${ }^{(23)}$. Considering the importance of work in people's lives, maintaining a healthy working environment can contribute to the quality of life and services provided, especially in situations where there is a need to make quick and precise decisions to save lives.

\section{Study limitations}

Data collection was performed in the workplace by the participants' choice. However, in some moments, the professional was called and interrupted the interview. Because of its quantitative focus, the study did not allow us to analyze the perceptions of the professionals involved about occupational stress and its forms of coping it.

\section{Study contributions}

This study allows a better understanding of the work process of nursing professionals working in Samu. Considering their work context, they are exposed to several occupational hazards. In this perspective, this research project reinforces the need of investment in actions and public policies of health promotion and the prevention of aggravations directed at these professionals.

\section{CONCLUSIONS}

The analysis of the factors related to the occupational stress of the nursing team of a Samu revealed that being a woman, sleep quality, work environment, restrictions on professional autonomy and emotional exhaustion with the work performed were factors, undoubtedly, associated with stress at work.

The participants with stress had predominance of physical symptoms, attributed to the physical overload and labor characteristics inherent to the service. The findings from this study show the need to follow the work and health conditions of nursing professionals, as well as the development of strategies that can minimize the damages to health, resulting from their work activities.

\section{REFERENCES}

1. Santos NAR, Santos J, Silva VR, Passos JP. Occupational stress in palliative care in oncology. Cogitare Enferm. 2017;22(4):e50686. doi: 10.5380/ce.v22i4

2. Ueno LGS, Bobroff MCC, Martins JT, Machado RCBR, Linares PG, Gaspar SG. Occupational stress: stressors referred by the nursing team. J Nurs UFPE On Line. 2017;11(4):1632-8. doi: 10.5205/1981-8963-v11i4a15232p1632-1638-2017

3. Machado DA, Figueiredo NMA, Velasques LS, Bento CAM, Machado WCA, Vianna LAM. Cognitive changes in nurses working in intensive care units. Rev Bras Enferm. 2018;71(1):73-9. doi: 10.1590/0034-7167-2016-0513

4. Fonseca JRF, Neto DL. Níveis de estresse ocupacional e atividades estressoras em enfermeiros de unidades de emergência. Rev Rene. 2014;15(5):732-42. doi: 10.15253/2175-6783.2014000500002

5. Andolhe R, Barbosa RL, Oliveira EM, Costa ALS, Padilha KG. Stress, coping and burnout among Intensive Care Unit nursing staff: associated factors. Rev Esc Enferm USP. 2015;49(spe):57-63. doi: 10.1590/S0080-623420150000700009

6. Oliveira EB, Gallash CH, Junior PPAS, Oliveira AVR, Valério RL, Dias LBS. Occupational stress and burnout in nurses of an emergency service: the organization of work. Rev Enferm UERJ. 2017;25:e28842. doi: 10.12957/reuerj.2017.28842

7. Lipp MEN, Guevara AJH. Validação empírica do Inventário de Sintomas de Stress (ISS). Estud Psicol. 1994;11(3):43-9.

8. Kestenberg CCF, Felipe ICV, Rossone FO, Delphim LM, Teotonio MC. The stress of nursing workers: study in different units of a university hospital. Rev Enferm UERJ. 2015;23(1):45-51. doi: 10.12957/reuerj.2015.11487

9. Lipp MEN. Inventário de sintomas de stress para adultos de Lipp (ISSL). São Paulo: Casa do Psicólogo; 2000. 
10. Rosso E, Júnior EJL, Aggio CM, Trincaus MR, Possolli GT, Zanoti-Gerônimo DV. Avaliação do nível de estresse entre os profissionais de enfermagem atuantes no SAMU de Guarapuava-PR. Braz J Surg Clin Res [Internet]. 2014 [cited 2016 Sep 11];7(1):13-7. Available from: https://www.mastereditora.com.br/periodico/20140602_103709.pdf

11. Muroya RL, Auad D, Brêtas JRS. Representações de gênero nas relações estudante de enfermagem e cliente: contribuições ao processo de ensino-aprendizagem. Rev Bras Enferm. 2011;64(1):114-22. doi: 10.1590/S0034-71672011000100017

12. Conselho Federal de Enfermagem (Cofen). Pesquisa perfil da enfermagem 2013 [Internet]. Brasília: Cofen; 2013 [cited 2017 Jan 10]. Available from: http://www.cofen.gov.br/perfilenfermagem/blocoBr/Blocos/Bloco1/bl_ident-socio-economica-equipe.pdf

13. Adriano MSPF, Almeida MF, Ramalho PPL, Costa IP, Nascimento ARS, Moraes JCO. Occupational stress among health professionals working in an emergency mobile care service in the city of Cajazeiras-PB. Rev Bras Ciênc Saúd. 2016;21(1):29-34. doi: 10.4034/RBCS.2017.21.01.04

14. Maia EC, Miranda MC, Caetano JA, Carvalho ZMF, Santos MCL, Caldini LN. Evaluation of the level of stress of the nursing of mobile emergence care service. Rev Pesq Cuidado Fund. 2012;4(4):3060-8. doi: 10.9789/2175-5361.2012.v4i4.3060-3068

15. Bezerra FN, Silva TM, Ramos VP. Occupational stress of nurses in emergency care: an integrative review of the literature. Acta Paul Enferm. 2012;25(2):151-6. doi: 10.1590/S0103-21002012000900024

16. Gallas SR, Fontana RT. Biossegurança e a enfermagem nos cuidados clínicos: contribuições para a saúde do trabalhador. Rev Bras Enferm. 2010;63(5):786-92. doi: 10.1590/S0034-71672010000500015

17. Nascimento MO, Araújo GF. Riscos ocupacionais dos profissionais de enfermagem atuantes no SAMU 192. Id On Line Rev Psic. 2017;10(33):212-23. doi 10.14295/idonline.v10i33.614

18. de la Cruz SP, Abellán MV. Professional burnout, stress and job satisfaction of nursing staff at a university hospital. Rev Latino-Am Enfermagem. 2015;23(3):543-52. doi: 10.1590/0104-1169.0284.2586

19. Valeretto FA, Alves DF. Triggering factors of occupation stress and burnout in nurses. Rev Saúde Fís Ment [Internet]. 2013 [cited 2018 Mar 19];3(2):1-11. Available from: https://revista.uniabeu.edu.br/index.php/SFM/article/view/1192

20. Hanna T, Mona E. Psychosocial work environment, stress factors and individual characteristics among nursing staff in psychiatric in-patient care. Int J Environ Res Public Health. 2014;11(1):1161-75. doi: 10.3390/ijerph110101161

21. Rahman HA, Abdul-Mumin K, Naing L. Psychosocial work stressors, work fatigue, and musculoskeletal disorders: comparison between emergency and critical care nurses in Brunei public hospitals. Asian Nurs Res (Korean Soc Nurs Sci). 2017;11(1):13-8. doi: 10.1016/j. anr.2017.01.003

22. Masiero M, Cutica I, Russo S, Mazzocco K, Pravettoni G. Psycho-cognitive predictors of burnout in healthcare professionals working in emergency departments. J Clin Nurs. 2018;27(13-14):2691-8. doi: 10.1111/jocn.14376

23. Bohström D, Carlström E, Sjöström N. Managing stress in prehospital care: strategies used by ambulance nurses. Int Emerg Nurs. 2016;32:2833. doi: 10.1016/j.ienj.2016.08.004 